\title{
Genetic Resource of the Resistance of Vicia faba L. against the Black Bean Aphid, Aphis fabae Scopoli
}

\author{
Fouad Meradsi
}

Laboratory of Improvement of the Phytosanitary Protection Techniques in Mountainous Agrosystems, Aureses Region. Agronomy Department, Institute of veterinary and Agricultural sciences, University of Batna -1- (05000), Algeria

Present address: 156 lodgings quoted, block 10, n 81 Batna-05000 Algeria

Malik Laamari

Laboratory of Improvement of the Phytosanitary Protection Techniques in Mountainous Agrosystems, Aureses Region. Agronomy Department, Institute of veterinary and Agricultural sciences, University of Batna -1- (05000), Algeria

Received: March 17, $2015 \quad$ Accepted: April 3, $2016 \quad$ Published: April 18, 2016

doi:10.5296/jas.v4i2.9333 URL: http://dx.doi.org/10.5296/jas.v4i2.9333

\begin{abstract}
The Black bean aphid Aphis fabae Scopoli (Homoptera: Aphididae) is a serious pest of faba bean, Vicia faba L. (Fabaceae) in Algeria. The use of resistant cultivars may reduce the impact of this pest on broad bean production and at the same time reduce environmental risks and control costs. The level of resistance of fourteen cultivars of broad bean, Vicia faba was screened in the field against the main aphid pest of faba bean, the Black bean aphid, Aphis fabae Scopoli during January to April 2011 in Biskra region (in the east of Algeria). Among the cultivars tested, six cultivars $(1,9,12,13,14$ and 15) were the most resistant in the three counts, while three cultivars $(4,6$ and 11) were showed a high susceptibility against this aphid at least once. The remainder of cultivars $(3,5,7,8$ and 10) revealed an unsettled level of resistance. The relationship between the level of resistance and morphological characters of cultivars indicated that the resistant cultivars have a longer leaflet than the high susceptible cultivars. In the other hand, the statistical analysis showed that no significant differences on the plant height and the leaflet width in the tow category of cultivars (resistant and high susceptible).
\end{abstract}

Keywords: Aphis fabae, cultivars, morphological character, resistance, Vicia faba.

\section{Introduction}

The broad bean, Vicia faba L. (Fabales: Fabaceae) is the most important food legume crop in Algeria with 42386 tons of dry matter (FAO stat, 2013). In Algeria, broad bean production 
includes highly diversified local cultivars. About 68 locally cultivars, have been identified by morphological and agronomic characterization (Meradsi, 2009).

Among the insects subservient to the bean aphids, occupy a very special place. On the plane damage, aphids are considered today among the most important insect pests inducing significant economic losses. They cause damage to both types. Direct damage correspond to multitudes of food taken, leading to a weakening of the plant, the abortion of flowers, rolling and falling leaves reducing photosynthetic area and drying of shoots (Delorme, 1997). Indirect ravages involved on the one hand by the affine system of fungus Fumago spp., designated by the concept sooty mold on the layer of honeydew expelled by aphids and secondly by the transmission of plant viruses.

The black bean aphid, Aphis fabae Scopoli (Homoptera: Aphididae) is the most destructive insect pest of broad bean, in Algeria. This aphid colonises a broad range of Fabaceae species (Bond and Lowe 1975; Cammell 1981; Cammell et al., 1989). Damage caused by the black bean aphid is of a notably indirect nature; by the transmission of viral diseases, such as the Broad bean wilt fabavirus (BBWV) and the Faba bean necrotic yellows nanovirus (FBNYV) (Franz et al., 1999). A. fabae is usually controlled using insecticides. However, the high costs of synthetic pesticides and associated toxicity risks (Mihale et al., 2009), the increasing development of insect resistance to pesticides, (Ogendo et al., 2003), the destruction of beneficial insects (pollinators, parasitoids and predators), pesticide residue magnification in humans and wildlife and disruption of ecosystem (Ruchika and Kumar, 2012), have increased the need to search for alternative insect control methods.

Plant resistance may be the most effective, economical, and environmentally sound management tactic to control A. fabae in crops. Recently, some progress has been archived in screening broad bean cultivars against black bean aphid and a number of cultivars have been identified as possible source of resistance for breeding programs (Khelfa, 2004; Meradsi, 2009).

The aim of this study was to evaluate the resistance of 14 locally cultivars of broad bean against the most pest of bean witch as the black bean aphid, A. fabae. A complementary objective was to research a possible relation between the level of resistance and morphological aspect of the cultivars.

\section{Materials and methods}

\subsection{Study area}

The two experiments were done at the Scientific and Technical Research Center for Arid Areas in Biskra (Algeria).

\subsection{Plant}

The plant material used in the first experiment conducted in field is composed of 14 broad bean cultivars, Vicia faba L. (Fabales: Fabaceae) collected from two locations situated in the east of Algeria: Biskra (9 cultivars) and Batna (5 cultivars) (Table 1). 
Table 1. Origin and code of cultivars tested

\begin{tabular}{|c|c|c|}
\hline Origin & Biskra & Batna \\
\hline Code of cultivars & $1,3,5,7,8,12,13,14$ and 15 & $4,6,9,10$ and 11 \\
\hline
\end{tabular}

\subsection{Insect}

The aphids used in the first experiment were obtained from a single apterous adult of Aphis fabae. They were collected in early February, 2011 from broad bean plants in a field situated at the region of Biskra. The aphids were reared on broad bean seedlings ( $V$. faba) under greenhouse conditions of $21 \pm 2^{\circ} \mathrm{C}, 60 \pm 5 \% \mathrm{RH}$ and 14: 10 (L: D) h photoperiod.

\subsection{Evaluation of the resistance in the field}

In the first experiment, the planting bean seeds representing 14 bean cultivars were produced at a rate of 12 seeds per cultivar. The depth seedling was $5 \mathrm{~cm}$. The spacing is $100 \mathrm{~cm}$ between rows and $90 \mathrm{~cm}$ between plants. The culture is conducted without insecticide treatment and without fertilization. According to El-Dafrawi et al. (1991), one apterous adult was placed on each plant at 13 growth stage (three leaves unfolded) (Mier, 2001). Counts of individuals within colonies formed on each plant are made 10, 20 and 30 days after infestation, firstly to see the best cultivars that resist $A$. fabae and also the persistence of this resistance with time (Meradsi, 2009; Lebbal, 2010).

The level of resistance of all cultivars adopted in this experiment was proposed by El-Dafrawi et al. (1991). The numbers of adults and nymphs were counted and assigned to four categories:

Grade 1: $\leq 5$ aphids; resistant cultivar

Grade 2: 6-20 aphids; tolerant cultivar

Grade 3: 21-50 aphids; susceptible cultivar

Grade 4: > 50 aphids; highly susceptible cultivar

\subsection{Relationship between level of resistance and morphological aspect of cultivars}

In objective to make a relationship between the morphology of cultivars and their level of resistance, a second experiment was achieved for the description of some organs of plants. The measures were carried out on the stems (the height of plant), foliage plants resistant cultivars (1 and 12) and highly susceptible cultivars (4 and 11) (the length and the width of the leaflet) according to the standards proposed by the UPOV (2003). The planting of 04 cultivars bean seeds was achieved due to 10 seeds per cultivar. The spacing is $100 \mathrm{~cm}$ between rows and $35 \mathrm{~cm}$ between plants.

Note: the code 3 that correspond the plant height, the code 9 that correspond the leaflet length and the code 10 correspond the leaflet width; these codes were proposed by the International Union for the Protection of new Varieties of Plants (UPOV, 2003). 


\subsection{Statistical analysis}

The data concerning the height plant (3), the leaflet length (basal pair of leaflet at secondary node) (9) and the leaflet width (basal pair of leaflet at secondary node) (10) were compared between resistant and highly susceptible cultivars using one-way analysis of variance (ANOVA) at $\mathrm{P} \leq 0.05$ (Gomez and Gomez, 1984). All statistical analyses were performed with SPSS statistical software (Version 10.0.5) (SPSS, 1999). The two experiments were designed in a randomized complete block design (RCBD).

\section{Results}

\subsection{Resistance in the field}

In the first count, 09 cultivars were classified as resistant. At the time in the second count, only 08 cultivars are resistant and 2 highly susceptible cultivars. Lasting the third count, 09 cultivars are classified resistant and only one highly susceptible cultivar (Table 2).

Table 2. Distribution of cultivars during the three counts (10, 20 and 30 days after infestation).

\begin{tabular}{|c|l|l|l|l|}
\hline \multirow{2}{*}{ Counts } & \multicolumn{4}{|c|}{ Level of the resistance } \\
\cline { 2 - 5 } & $\begin{array}{l}\text { Resistant cultivars } \\
(\leq 5 \text { aphids })\end{array}$ & $\begin{array}{c}\text { Tolerant } \\
\text { cultivars }(6-20 \\
\text { aphids })\end{array}$ & $\begin{array}{c}\text { Susceptible } \\
\text { cultivars } \\
(21-50 \text { aphids })\end{array}$ & $\begin{array}{c}\text { Highly susceptible } \\
\text { cultivars }(>50 \\
\text { aphids })\end{array}$ \\
\hline The first & $\begin{array}{l}1,5,7,8,9,12,13, \\
14 \text { and } 15\end{array}$ & $\begin{array}{l}3,4,6,10 \text { and } \\
11\end{array}$ & - & - \\
\hline The second & $\begin{array}{l}1,5,9,10,12,13, \\
14 \text { and } 15\end{array}$ & 4 and 7 & 3 and 8 & 6 and 11 \\
\hline The third & $\begin{array}{l}1,3,6,9,10,12, \\
13,14 \text { and } 15\end{array}$ & 7 and 11 & 5 and 8 & 4 \\
\hline
\end{tabular}

\subsection{Relationship between the level of resistance and morphological character of cultivars}

The table 3 indicated all the results concerning the measures on the stems and foliage of resistant (1 and 12) and highly susceptible (4 and 11) cultivars.

Table 3. Morphological characters of resistant and highly susceptible cultivars.

Legend:

3: The height of plant $(\mathrm{cm}), 9$ : the length of the leaflet $(\mathrm{cm}), 10$ : the width of the leaflet $(\mathrm{cm})$.

\begin{tabular}{|c|c|c|c|c|c|c|c|c|c|c|c|c|}
\hline \multirow{4}{*}{ Plants } & \multicolumn{12}{|c|}{ Cultivars } \\
\hline & \multicolumn{3}{|c|}{1} & \multicolumn{3}{|c|}{4} & \multicolumn{3}{|c|}{11} & \multicolumn{3}{|c|}{12} \\
\hline & \multicolumn{12}{|c|}{ Morphological characters } \\
\hline & 3 & 9 & 10 & 3 & 9 & 10 & 3 & 9 & 10 & 3 & 9 & 10 \\
\hline 1 & 18.5 & 05.5 & 03.9 & 09.9 & 04.5 & 03.6 & 09.7 & 05.5 & 03.7 & 04.4 & 04.4 & 02.5 \\
\hline 2 & 14 & 04.6 & 03.5 & 11.6 & 04 & 02.2 & 11.3 & 04.4 & 03.2 & 11.1 & 04.9 & 02.3 \\
\hline 3 & 14.7 & 05.2 & 02.6 & 13.1 & 04.1 & 03.3 & 07.4 & 03.9 & 02.6 & 06.1 & 03.4 & 01.6 \\
\hline 4 & 13.1 & 05.8 & 03.3 & 15.3 & 04.5 & 03.5 & 10.2 & 05.3 & 02.8 & 10.3 & 03.5 & 019 \\
\hline 5 & 12.4 & 05.3 & 02.4 & 11.5 & 04.7 & 03.2 & 11.3 & 03.6 & 02.7 & 14.1 & 04.7 & 02.6 \\
\hline
\end{tabular}




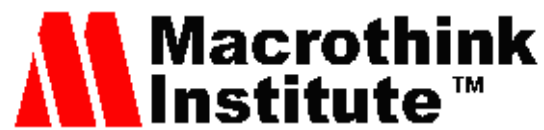

\begin{tabular}{|c|c|c|c|c|c|c|c|c|c|c|c|c|}
\hline 6 & 13.7 & 05.6 & 03.7 & 08 & 03.6 & 02.4 & 11.3 & 04 & 02.9 & 08.9 & 03.8 & 02.3 \\
\hline 7 & 12.1 & 05.7 & 02.7 & 11.3 & 04 & 02.4 & 09.4 & 04 & 02.6 & 06.3 & 03.6 & 02.6 \\
\hline 8 & 15.3 & 05.9 & 03.4 & 07.6 & 03.9 & 02.8 & 10.4 & 04.3 & 02.8 & 11.4 & 03.3 & 02.5 \\
\hline 9 & 13 & 05.3 & 02.6 & 07.8 & 03 & 02.3 & 09.7 & 04.8 & 03.3 & 10.3 & 05.1 & 02.4 \\
\hline 10 & 11 & 05.8 & 03 & 09 & 03.5 & 01.6 & 09.8 & 04 & 01.9 & 07.3 & 03.4 & 01.7 \\
\hline
\end{tabular}

Statistical analysis showed no significant difference (P>0.05) between the resistant and highly susceptible cultivars for the tow characters: the plant height (3) and the leaflet width (10). In contrast, the results indicated a significant difference among the resistant and highly susceptible cultivars for the character of the leaflet length (9) $\left(\mathrm{F}_{4.10}=5.15 ; \mathrm{P}=0.029\right)$. The resistant cultivars have a longer leaflet than the highly susceptible cultivars (Table 4).

Table 4. Relationship between level of the resistance and morphologic of resistant and highly susceptible cultivars.

$\mathrm{n}$ : number of replications, ns: not significant. Values followed by different letters within a column are significantly different (ANOVA: ${ }^{*} \mathrm{P}<0.05$ ).

\begin{tabular}{|c|c|c|c|c|c|}
\hline $\begin{array}{c}\text { Morphological } \\
\text { character }\end{array}$ & Level of resistance & Means \pm SE & $\mathrm{n}$ & $\mathrm{F}_{4.10}$ & $\mathrm{P}$ \\
\hline $\begin{array}{c}\text { The plant height; } 3 \\
(\mathrm{~cm})\end{array}$ & Resistant cultivars & $10.40 \pm 0.78 \mathrm{a}$ & 20 & 1.576 & $\begin{array}{c}0.217 \\
(\mathrm{~ns})\end{array}$ \\
\cline { 2 - 3 } & Highly susceptible cultivars & $10.28 \pm 0.43 \mathrm{a}$ & & & \\
\hline $\begin{array}{c}\text { The leaflet length; } \\
9(\mathrm{~cm})\end{array}$ & Resistant cultivars & $4.74 \pm 0.21 \mathrm{a}$ & 20 & 5.154 & $0.029^{*}$ \\
\cline { 2 - 3 } & Highly susceptible cultivars & $4.18 \pm 0.13 \mathrm{~b}$ & & & \\
\hline $\begin{array}{c}\text { The leaflet width; } \\
10(\mathrm{~cm})\end{array}$ & Resistant cultivars & $2.67 \pm 0.14 \mathrm{a}$ & 20 & 0.372 & $\begin{array}{c}0.546 \\
(\mathrm{~ns})\end{array}$ \\
\cline { 2 - 3 } & Highly susceptible cultivars & $2.79 \pm 0.13 \mathrm{a}$ & & &
\end{tabular}

\section{Discussion}

The results obtained during the three counts allowed to classify broad bean cultivars studied according to their level of resistance to A. fabae. Among the cultivars tested, six cultivars $(1,9$, $12,13,14$ and 15) were the most resistant in the three counts, while three cultivars $(4,6$ and 11) were showed a high susceptibility against this aphid at least once. Similar work is carried out by several authors. In 2009, Meradsi, found 19 resistant cultivars among 68 cultivars of $V$. faba tested against A. fabae. Lebbal (2010), during work on the resistance of broad bean against alfalfa aphid has selected 16 resistant cultivars among 62 cultivars tested. . In other work, Khelfa (2004) was selected 6 resistant cultivars against A. craccivora among 48 cultivars collected in the Biskra region. In Egypt, after 4 years of study on resistance of 7156 bean cultivars against $A$. craccivora, El-Defrawi et al. (1991) were able to select 114 resistant cultivars.

On these resistant cultivars, installed aphids are difficult to meet their basic needs. For this reason, they produce fewer individuals compared to those reared on susceptible cultivars. Indeed, Kordan et al. (2008) demonstrated that the fertility of the pea aphid, Acyrthosiphon pisum on lupine resistant plants was between 0.1 and 0.4 larvae, while it was 17.4 individuals on a susceptible cultivar. In other study, Ma et al. (2006) found that females of the aphid Sitobion avenae produced less than 300 larvae in 100 ears of the resistant cultivar "KOK 1679» against 1400 individuals on the susceptible cultivar 'Lovrin 10'.

The results achieved in the field only a partial estimate of the resistance. Aphid colonies 
counted on the plants do not actually correspond to those issued by the females used in artificial infestation. Other parameters such as edge effects, the age of the plant, the attractivity of the cultivar, seed quality and installation of auxiliary insects can participate in the increase or decrease of insects.

Since the plants are not covered, individuals initially used in artificial infestation of plants or their progeny can settle freely on the most attractive cultivars to participate in an additional infestation. Possible natural contamination can also occur.

In the field, the setting chosen for the evaluation of cultivar resistance and is based on the importance of aphid colonies express much resistance by antibiotic mechanisms and antixenotic not plant tolerance.

Resistance bean cultivars can be attributed to morphological and biochemical factors. Among the morphological factors, there are especially the thickness and structure of the wax layer covering the plant. The color and size of the foliage are other morphological parameters that can also be involved in this resistance. Indeed, the results presented in the table 6 showed that resistant cultivars are characterized by long leaflets compared to highly susceptible cultivars. In contrast, Meradsi (2009) found that the highly susceptible cultivars bean have a narrow leaflets than the resistant cultivars. Lebbal (2010) mentioned that the bean resistant cultivars or highly susceptible have the same morphological characters. Similarly, Tolmay et al. (1999) noted that the susceptible cultivars are those with narrow leaves in wheat.

The quality of food offered by the host plant to its biological pests is another parameter that determines their development, growth and reproduction. For example, the amino acid composition of the superficial plant tissues can determine the nutritional behavior of aphids. Cisneros and Godfrey (2001) found that there is a positive correlation between the abundance of Aphis gossypii on cotton plants and the content of the nitrogen in plants. Mustapha and Samara (1999) reported on their part that the variety of the bean supported infestation by $A$. fabae is the plant that contains the lowest level of nitrogen and phosphor rate on higher. Probably, the bean resistant cultivars to A. fabae those are poor in nitrogen and sugars and more or less rich in phosphor.

\section{Conclusion}

In light of the results obtained, it is observed that among the 14 cultivars tested in this study, 12 are classified as resistant to $A$. fabae at least once. While 6 cultivars (1, 9, 12, 13, 14 and 15) have retained this level of resistance in the three counts made. In contrast, 03 cultivars $(4,6$ and 11) are considered highly susceptibles at least once. The resistant cultivars have long leaflets than the highly susceptible cultivars. It would be interesting also to identify the quality and quantity of volatiles repulsive resistant cultivars by the coupling of gas chromatography and mass spectrometry. The Determining of the thickness and the chemical composition of the wax of resistant cultivars that covers its leaves can also contribute to the explanation of its resistance level. 


\section{Acknowledgements}

The research is financed by Ministry of the Higher Education and the Scientific Research. The authors thank the staff of the Scientific and Technical Research Center for Arid Areas (Biskra, Algeria) for their assistance.

\section{References}

Bond, D. A., \& Lowe, H. J. B. (1975). Tests for resistance to Aphis fabae in field beans (Vicia faba). Annals of Applied Biology, 81(1), 21-32

Cammell, M. E. (1981). The black bean aphid, Aphis fabae. Biologist, 28, 247-258

Cammell, M. E., Tatchell, G. M., \& Woiwod, I. P. (1989). Spatial pattern of abundance of the black bean aphid, Aphis fabae, in Britain. Journal of Applied Ecology, 26(2), 463-472

Cisneros, J. J., \& Godfrey, L. D. (2001). Midseason pest status of the cotton aphid (Homoptera: Aphididae) in California cotton: is nitrogen a key factor? Environmental Entomology, 30, 501-510

Delorme, R. (1997). Aphids and insecticides: Prevention and management of the resistances. Cultures Légumières, special number: Environment, june, 11-15 (in French)

El-Defrawi, G., El-Gantiry, A. M., Weigand, S., \& Khalil, S. A. (1991). Screening of faba bean (Vicia faba L.) for resistance to Aphis craccivora Koch. Arab Journal of Plant Protection, 9(2), 138-141

FAO, stat. (2013). Statistical Division. Available: http:// www.faostat.fao.org (September 27, 2015).

Franz, A. W., van der Wilk, F., Verbeek, M., Dullemans, A. M., \& van den Heuvel, J. F. (1999). Faba bean necrotic yellows virus (genus Nanovirus) requires a helper factor for its aphid transmission. Virology, 262(1), 210-219

Gomez, K. A., \& Gomez, A. A. (1984). Statistical procedures for agricultural research, $\left(4^{\text {th }}\right.$ ed.). John Willy and Sons-Inco. New York. p. 680.

Khelfa, L. (2004). Study of the resistance of different varieties of broad bean against the cowpea aphid, Aphis craccivora Koch, 1854 (Homoptera: Aphididae) in Biskra region. Master degree thesis in plant protection. University of Batna. Algeria, 134. (in French)

Kordan, B., Gabryś, B., Dancewicz, K., Lahuta, L. B., Piotrowicz-Cieślak, A., \& Rowińska, E. (2008). European yellow lupine, Lupinus luteus, and narrow-leaf lupine, Lupinus angustifolius, as hosts for the pea aphid, Acyrthosiphon pisum. Entomologia Experimentalis et Applicata, 128, 139-146. http://dx.doi.org/10.1111/j.1570-7458.2008.00702.x

Lebbal, S. (2010). Contribution to the study of natural resistance of the broad bean, Vicia faba L. against the cowpea aphid, Aphis craccivora (Homoptera : Aphididae). Master degree thesis in Plant protection. University of Batna. Algeria. 66. (in French)

Ma, X. M., Liu, X. X., Zhang, Q. W., Zhao, J. Z., Cai, Q. N., Ma, Y. A., \& Chen, D. M. 
(2006). Assessment of cotton aphids, Aphis gossypii, and their natural enemies on aphid-resistant and aphid-susceptible wheat varieties in a wheat-cotton relay intercropping system. Entomologia Experimentalis et Applicata, 121, 235-241. http://dx.doi.org/10.1111/j.1570-7458.2006.00484.x

Meradsi, F. (2009). Contribution to the study of natural resistance of the broad bean, Vicia faba L. against the black bean aphid, Aphis fabae Scopoli, 1763 (Homoptera : Aphididae). Master degree thesis in Plant protection. University of Batna. Algeria. 83. (in French)

Mier, U. (2001). Growth stages of mono-and dicotyledonous plants. BBCH Monograph, Federal Biological Research Centre for Agriculture and Forestry, 158.

Mihale, M. J. Deng, A. L.; Selemani, H. O. Mugisha-Kamatenesi, M. Kidukuli, A. W., \& Ogendo, J. O. (2009). Use of Indigenous knowledge in the management of field and storage pests around Lake Victoria basin in Tanzania, African Journal of Environmental Science and Technology, 3(9), 251-259

Mustapha, T. M., \& Samara, Y. R. (1999). Reproductive power and capacity of infestation by the black bean aphid on some varieties of bean. Arab Journal of Plant Protection, 17(1), 41-44 (in Arabic)

Ogendo, J. O. Belmain, S. R. Deng, A. L., \& Walker, D. J. (2003). Comparison of toxic and repellent effects of Lantana camara L. with Tephrosia vogelii hook and a synthetic pesticide against Sitophilus zeamais Motschulsky (Coleoptera: Curculionidae) in stored maize grain, Insect science and its Application, 23(2), 127-135

Ruchika, K., \& Kumar, D. (2012). Occurrence and infestation level of sucking pests: Aphids on various host plants in agricultural fields of Vadora, Gujarat (India), International Journal of Scientific and Research Publications, 2(7), 1-6

SPSS, Inc. (1999). SPSS for Windows, Version 10.0.5, Chicago, Illinois.

Tolmay, V. L., van der Westhuizen, M. C., \& van Deventer, C. S. (1999). A six week screening method for mechanisms of host plant resistance to Diuraphis noxia in wheat accessions. Euphytica, 107, 79-89

UPOV (International Union for the Protection of new Varieties of Plants). (2003). Broad Bean (Vicia faba L. var. major Harz). Leading principles for the conduct of the exam, the distinction, the homogeneity and the stability, 30.

\section{Copyright Disclaimer}

Copyright for this article is retained by the author(s), with first publication rights granted to the journal.

This is an open-access article distributed under the terms and conditions of the Creative Commons Attribution license (http://creativecommons.org/licenses/by/3.0/). 